\title{
Inleiding
}

\section{Het Regionaal colloquium neerlandicum „Bruggen slaan" van Comenius, Vereniging voor neerlandistiek in Centraal-Europa}

Dit themanummer van de Brünner Beiträge zur Germanistik und Nordistik bundelt enkele taalkundige en vertaalkundige bijdragen van het regionaal colloquium neerlandicum „Bruggen slaan“, dat plaatsvond van 29 mei tot 1 juni 2019 te Bratislava. Twintig jaar geleden werd precies ook dan een regionaal colloquium in Bratislava georganiseerd. Voor deze speciale gelegenheid in mei hadden wij het genoegen om op feestelijke wijze het emeritaat te kunnen vieren van prof.dr. Jana Rakšányiová, die jarenlang het hoofd was van de sectie neerlandistiek van de Comenius Universiteit te Bratislava. Bij dit colloquium werd ook een vertaling voorgesteld van het boek „Samen op de laan van Europa. 100 jaar Tsjechië en Slowakije in Nederland" van Jan C. Henneman, Pieter Goedhart, Kryštof en Rebecca Krijt en Ivo Mostert, een boek dat ook een brug legt tussen onze landen en de Nederlandse cultuur.

We kozen voor het thema „Bruggen slaan“, omdat neerlandistiek bij uitstek een vakgebied is, dat interdisciplinariteit omarmt en onderzoeksbijdragen uit verschillende disciplines verwelkomt. Omdat de vakgebieden zo uiteenlopend zijn, hebben wij ervoor gekozen om ons in dit themanummer te beperken tot de vertaalkunde en de taalkunde.

De bijdragen zijn als volgt genummerd. In een eerste lijn bevatten zes artikels bijdragen uit het onderzoek binnen de vertaalkunde, literair vertalen, vertaaldidactiek en tolkwetenschappen. Als eerste bijdrage een onderzoek van de Wrocławse promovendus Michał GA_SKA naar specifieke medische vaktermen in de Britse televisieserie „Call the Midwives“, waarbij ondertitels in zowel de Poolse als Nederlandse versie werd bekeken. Veronika HORÁČKOVÁ gaat in op literair vertalen en kwesties in verband met Tsjechisch literair vertalen. Zij vergelijkt daarbij vertalingen van twee romans uit de streekliteratuur van Anton Coolen naar het Tsjechisch. Ook het derde artikel behandelt vertaalaspecten, maar dan vanuit de hoek van het beoordelen van juridische vertalingen. Hier stellen Milan POTOČÁR en Benjamin BOSSAERT in hun artikel een nieuwe mogelijke beoordelingsmethode centraal om rechtsteksten bij een examen tot beëdigd vertalen te evalueren. In de vierde tekst gaat het over vertaaldidactiek. Muriel WATERLOT onderzoekt bij de 
studenten met behulp van vragenlijsten hun attitude tegenover vertalen in de lesdidactiek Nederlands als Vreemde taal in Polen. Michal HOMOLA zet in zijn aanzet tot onderzoek een stand van zaken uiteen in het veld van het zogenaamde Public Service Interpreting and Translation, een vakgebied binnen de vertaal- en tolkwetenschappen dat nog volop in ontwikkeling is op onderzoeksgebied in de regio Centraal-Europa en specifiek hier in dit artikel in Slowakije. Ekaterina TERESHKO presenteert een case-study van de vertaling van een cultuurspecifiek Nederlands boek, het DNA van het Nederlands van Jan Renkema. Zij geeft enkele conclusies over de vertaling naar het Russisch.

In de tweede lijn presenteren we artikelen die didactisch en taalkundig gericht zijn. Camiel HAMANS houdt zich bezig met morfologie en presenteert een onderzoek naar blends en probeert in Nederlandse, Engelse en Duitse woordblends een systematiek aan te brengen. Sofie ROYEAERD legt zich toe op het onderzoek naar verstaanbaarheid van de verschillende vormen van het standaardnederlands in Nederland en België en toetst deze aan het studentenpubliek Nederlands als Vreemde Taal in Midden-Europa. Tot slot nemen we van verstaanbaarheid een brug naar fonetische verschillen bij Poolse studenten in de bijdrage van Zuzanna CZERWONKA-WAJDA. Zij gaat na of bij de uitspraak van vormen van [e] en [عi] -klanken er verschillen zijn bij de auditieve en articulatorische competentie.

We willen graag onze dank uitdrukken aan de organisaties die dit alles hebben mogelijk gemaakt. In de eerste plaats de Nederlandse Taalunie als hoofdsponsors, daarnaast ook de Algemene Afvaardiging van de Vlaamse Vertegenwoordiging in Slowakije zetelend te Wenen, de Ambassade van het Koninkrijk der Nederlanden in Slowakije, de afdeling Keerbergen van de organisatie Orde van den Prince en de decaan van de Comenius Universiteit.

lic. Benjamin Bossaert / benjamin.bossaert@uniba.sk

Univerzita Komenského, Katedra germanistiky, nederlandistiky a škandinavistiky, Gondova 2, 81499 Bratislava, SK

doc. mgr. Marketa Štefková, PhD. / marketa.stefkova@uniba.sk

Univerzita Komenského, Katedra germanistiky, nederlandistiky a škandinavistiky, Gondova 2, 81499 Bratislava, SK

Mgr. Marta Kostelecká, PhD. / marta.kostelecka@gmail.com Masarykova univerzita, Filozofická fakulta, Ústav germanistiky, nordistiky a nederlandistiky, Arna Nováka 1, 60200 Brno, CZ 